\title{
Morphological and molecular analysis of metacercariae of Diphtherostomum brusinae (Stossich, 1888) Stossich, 1903 from a new bivalve host Mytilus galloprovincialis
}

\author{
C.J. Francisco ${ }^{1,2 *}$, A. Almeida ${ }^{3,4}$, A.M. Castro ${ }^{3}$, S. Pina ${ }^{4}$, \\ F. Russell-Pinto ${ }^{2,4}$, P. Rodrigues ${ }^{4}$ and M.J. Santos ${ }^{1,2}$ \\ ${ }^{1}$ Departamento de Biologia, Faculdade de Ciências, Universidade do \\ Porto, FC4, Rua do Campo Alegre s/n, 4169-007 Porto, Portugal: ${ }^{2}$ CIMAR \\ Laboratório Associado/CIIMAR, Centro Interdisciplinar de Investigação \\ Marinha e Ambiental, Rua dos Bragas, 289, 4050-123 Porto, Portugal: \\ ${ }^{3}$ Departamento de Doenças Infecciosas, Instituto Nacional de Saúde \\ Dr Ricardo Jorge, Rua Alexandre Herculano, 321, 4000-055 Porto, Portugal: \\ ${ }^{4}$ Instituto de Ciências Biomédicas de Abel Salazar, Largo Prof. Abel \\ Salazar, 2, 4099-003 Porto, Portugal
}

(Accepted 14 July 2010)

\begin{abstract}
The digenean trematode Diphtherostomum brusinae (Stossich, 1888) Stossich, 1903 presents a complex life cycle that may involve more than one intermediate host. The present study represents the first description of the metacercariae from $D$. brusinae infecting the labial palps of a new intermediate host, Mytilus galloprovincialis, in the Aveiro estuary, Portugal. The morphology of this parasitic stage was studied by light (LM) and scanning electron microscopy (SEM) and some differences were reported (body and sucker sizes, and spine distribution and shape). In this work, the $18 \mathrm{~S}$ partial region of the ribosomal DNA was sequenced from $D$. brusinae metacercariae isolated from $M$. galloprovincialis collected in different localities of the Aveiro estuary. In addition, sequences from the same region of the $18 \mathrm{~S}$ rDNA were obtained from $D$. brusinae cercariae and metacercariae, hosted by Nassarius reticulatus and Cerastoderma edule, respectively. No intraspecific polymorphism was detected in the $18 \mathrm{~S}$ partial region, since there was $100 \%$ homology among all the sequences analysed. The same comparison was made for the ITS1, and we observed intraspecific polymorphism in this region. To our knowledge, this is the first report of $D$. brusinae metacercariae infecting the mussel M. galloprovincialis with support from morphological and molecular data.
\end{abstract}

\section{Introduction}

The trematode Diphtherostomum brusinae (Stossich, 1888) Stossich, 1903 has a complex life cycle, infecting successive hosts in the marine environment: the development of the adult stage occurs in the digestive tract of

\footnotetext{
*E-mail: clairejulianaf@yahoo.com.br
}

the definitive host, a fish, which can belong to different families (Sparidae, Gobiidae, Labridae, Blenniidae), where it reproduces sexually and produces eggs that will be released with the host faeces. The first larval phase in the worm's life cycle - the development of the miracidium - takes place inside the egg. This miracidium infects the prosobranchs Nassa mutabilis, Nassarius reticulatus and Natica poliana. In this first intermediate 
host, they develop into sporocysts, which reproduce asexually and generate innumerable cercariae which may encyst directly inside sporocysts; N. mutabilis, $N$. reticulatus, $N$. poliana and Cyclope donovani can serve as first and second hosts. Venus gallina, Spisula subtruncata and Cerastoderma edule serve as second intermediate hosts. The definitive host, a fish, is infected by consumption of the molluscs or the metacercariae encysted on vegetable supports, thus closing the life cycle (Pina et al., 2009).

In southern Europe, the bivalve Mytilus galloprovincialis (Lamarck, 1819) is a highly appreciated mollusc, and therefore an important commercial species. A recent parasitological survey revealed the presence of several parasite species on M. galloprovincialis (Francisco et al., 2010). Infections of this mussel, especially by trematodes, may have a negative impact on its commercial production, for example Prosorhynchus crucibulum causing mussel castration (Francisco et al., 2010). In the same study the most prevalent trematode was D. brusinae (there reported as Diphtherostomum sp.) which occurred in $58 \%$ of the mussels, causing histopathological alterations in the labial palp tissue. These data made us focus on the characterization of this species. Molecular techniques are a useful tool that may help elucidate the complex life cycle of these parasites. Recent molecular data of $D$. brusinae were obtained based on the ribosomal operon, particularly the internal transcriber spacer 1 (ITS1) (Pina et al., 2009), while no data on the 18S region had been reported so far for this species. Generating more molecular data for this and other loci is important to understand the epidemiology of this parasite.

The main aim of this study was to identify and characterize, using morphological and molecular tools, the larval stage of this parasite, isolated from a new host, M. galloprovincialis, collected from three different locations in the Aveiro estuary, Portugal. A comparison with $D$. brusinae hosted by $N$. reticulatus (cercariae) and C. edule (metacercariae) is also provided.

\section{Materials and methods}

\section{Species characterization}

Mytilus galloprovincialis were collected, in January 2009, from three different places in the Aveiro estuary: site A $\left(40^{\circ} 38.62^{\prime} \mathrm{N} ; 8^{\circ} 44.80^{\prime} \mathrm{W}\right)$, site B $\left(40^{\circ} 39.84^{\prime} \mathrm{N} ; 8^{\circ} 43.59^{\prime} \mathrm{W}\right)$ and site $\mathrm{C}\left(40^{\circ} 40.76^{\prime} \mathrm{N} ; 8^{\circ} 43.08^{\prime} \mathrm{W}\right)$ (fig. 1). They were maintained in laboratory tanks with aerated water from the same location. Mussels were dissected in order to detect the presence of $D$. brusinae metacercariae. Organs were removed and microscopically examined for cyst detection. Freshly isolated cysts were observed, measured, photographed and stored in $70 \%$ ethanol for DNA extraction. Metacercariae $(n=30)$ were excysted with the aid of a histological needle and their anatomy observed by light microscopy (LM) (using a Zeiss Axiophot; Zeiss, Sintra, Portugal). Photographs were taken using the digital camera Zeiss Axiocam Icc3 and image analysis software (AxioVision 4.6, Zeiss). The worms were identified by morphology according to the Zoogonidae and Diphtherostomum Stossich, 1903 keys provided by Bray $(1986,2001)$ and Bray \& Gibson (1986).

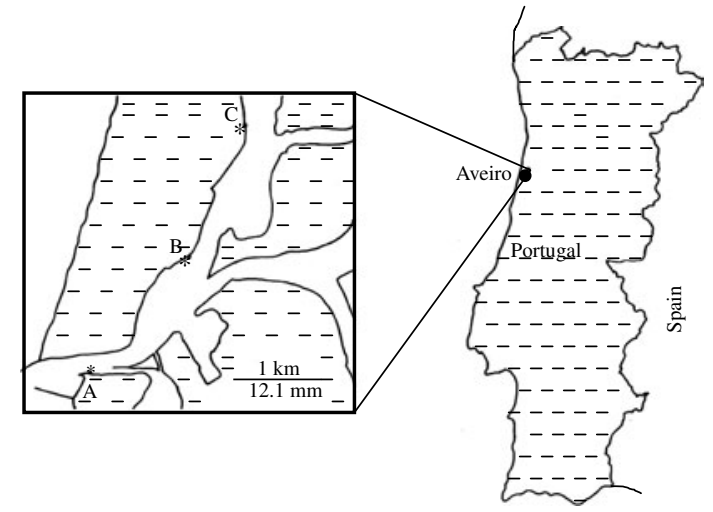

Fig. 1. Map showing the three sampling localities (A, Barra channel; B, São Jacinto; C, São Jacinto) for Mytilus galloprovincialis, in the Aveiro estuary, Portugal.

For scanning electron microscopy (SEM), metacercariae were dehydrated through a graded ethanol series (70-100\%). The samples were critical point dried in $\mathrm{CO}_{2}$, mounted, and coated with gold-palladium. Photomicrographs were obtained with a JEOL-JSM-6301 F scanning electron microscope operating at $15 \mathrm{kV}$.

\section{Primer design, DNA extraction, PCR and sequencing}

Primers were designed after we obtained nucleotide sequences from the literature from several homologous sequences of related parasites (Hall et al., 1999). Primers were designed from the alignment target, a fragment of the $18 S$ rDNA gene. A previously developed standard polymerase chain reaction (PCR) assay targeting the ITS1 gene was used under the experimental conditions described by Pina et al. (2009) over two randomly chosen individuals of $D$. brusinae.

Worms from M. galloprovincialis from the previous collection were washed in saline solution and stored in $70 \%$ ethanol. A commercial kit (QIAGEN, Porto, Portugal) was used to extract DNA from individual encysted metacercariae in the nine samples (three from each collection point), according to the manufacturer's protocol. Additionally, DNA was extracted from 110 naturally emitted cercariae from $N$. reticulatus and 118 cysts obtained from C. edule. A partial region of the $18 \mathrm{~S}$ rDNA, a highly conserved region, was amplified using the primers designed as described above: SSU_Fwd (5'-TCTGGGTCGCATC-3') and SSU_Rev (5'-CCATTACTTCGGATC- $\left.3^{\prime}\right)$. PCR amplifications were performed in a total volume of $50 \mu \mathrm{l}$. Every reaction contained $5 \mu \mathrm{l}$ of PCR buffer $10 \times, 4 \mathrm{mM} \mathrm{MgCl}_{2}, 0.2 \mathrm{~mm}$ dNTPs, $200 \mathrm{nM}$ of each primer, 1 standard unit Taq polymerase and 5-10 $\mu \mathrm{l}$ template DNA. The mix was placed in a ThermoCycler Primus 25/96 (Hain Lifescience, Porto, Portugal) with the following conditions: initial hot start of $94^{\circ} \mathrm{C}$ for $4 \mathrm{~min}$, followed by 40 cycles of $95^{\circ} \mathrm{C}$ for $30 \mathrm{~s}, 40^{\circ} \mathrm{C}$ for $30 \mathrm{~s}$ and $72^{\circ} \mathrm{C}$ for $30 \mathrm{~s}$. Final extension of the product was at $72^{\circ} \mathrm{C}$ for $5 \mathrm{~min}$.

After amplification, the PCR products were analysed by electrophoresis in a 1\% agarose gel (BioRad, Amadora, Portugal) stained with ethidium bromide, and fragment 
sizes were estimated using a $\lambda$ DNA/Hindlll digest ladder (NewEngland BioLabs, Carnaxide, Portugal). For PCR product purification, a low melting $1 \%$ agarose gel was made (Promega, Lisbon, Portugal) and a commercial kit (GFX PCR DNA and Gel band purification kit, GE Healthcare, Barcelona, Spain) was used according to the manufacturer's instructions. DNA fragments were sequenced in both strands in an external laboratory (Eurofins MWG Operon, Germany). Sequences obtained were compared with the sequences in GenBank by the Basic Local Alignment Search Tool BLAST (www.ncbi.nlm.nih.gov). These sequences were aligned within PROSEQ ${ }^{\circledR}$ version 2.91 (ProSeq, http:/ / helios.bto. ed.ac.uk/evolgen/filatov/proseq.html) and deposited in GenBank.

\section{Results}

\section{Morphological characterization}

Host. Mytilus galloprovincialis (Lamarck, 1819) as second intermediate host.

Site of infection. Encysted metacercariae in the labial palp tissue.
Locality. Site A $\left(40^{\circ} 38.62^{\prime} \mathrm{N} ; 8^{\circ} 44.80^{\prime} \mathrm{W}\right)$, site B $\left(40^{\circ} 39.84^{\prime} \mathrm{N}\right.$; $\left.8^{\circ} 43.59^{\prime} \mathrm{W}\right)$ and site $\mathrm{C}\left(40^{\circ} 40.76^{\prime} \mathrm{N} ; 8^{\circ} 43.08^{\prime} \mathrm{W}\right)$ in the Aveiro estuary, northern Portugal.

Metacercariae. The cyst walls were transparent and the metacercariae could be observed coiled inside the cysts (fig. 2A). In excysted metacercariae (fig. 2B) the forebody was more elongated than the hindbody. Dimensions (average \pm standard deviation (range)) were based on 30 excysted metacercariae: body $408.6 \pm 123.2(224-612) \mu \mathrm{m}$ long; oral sucker $34.5 \pm 12$ (16-89) $\mu \mathrm{m}$ diameter; ventral sucker $54.2 \pm 14.6$ (29-114) $\mu \mathrm{m}$ diameter; sucker diameter ratio 1:1.6. Two symmetrical testes were posterior to the ventral sucker (fig. 2C). Prepharynx unrecognizable; oesophagus $129.2 \pm 50.8$ (53-266) $\mu \mathrm{m}$ long, bifurcated at the anterior border of the ventral sucker; two caeca short, saccular and divergent extending to the opening of the ventral sucker (fig. 2D).

Using SEM, we could observe that the metacercaria body surface was covered with regularly distributed spines (fig. 3A). The morphology and size of the spines changed with the body region. Next to the oral region the spines were small and pointed (fig. 3B); in the ventral to pre-acetabular region, they were strong and rounded (fig. 3C). A ring with 16 papillae was observed around
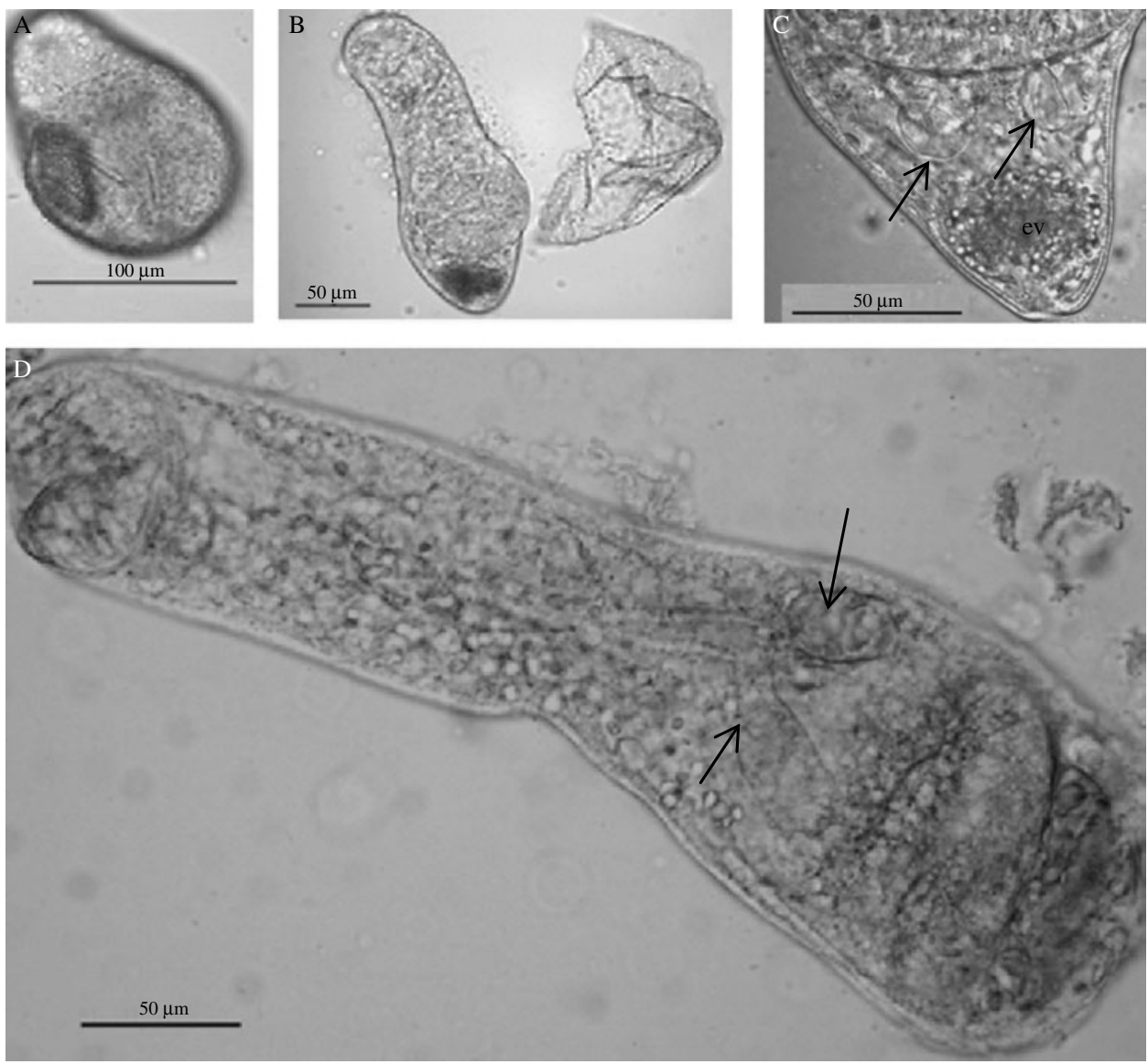

Fig. 2. Metacercariae of Diphtherostomum brusinae: (A) cyst with transparent wall and the metacercaria inside the cyst; (B) excysted metacercaria shows forebody more elongated than hindbody; $(C)$ two symmetrical testes (arrows) posterior to ventral sucker and excretory vesicle (ev); (D) caeca (arrow) short, saccular and divergent. Scale bars: $100 \mu \mathrm{m}(\mathrm{A}) ; 50 \mu \mathrm{m}(\mathrm{B}, \mathrm{C}, \mathrm{D})$. 

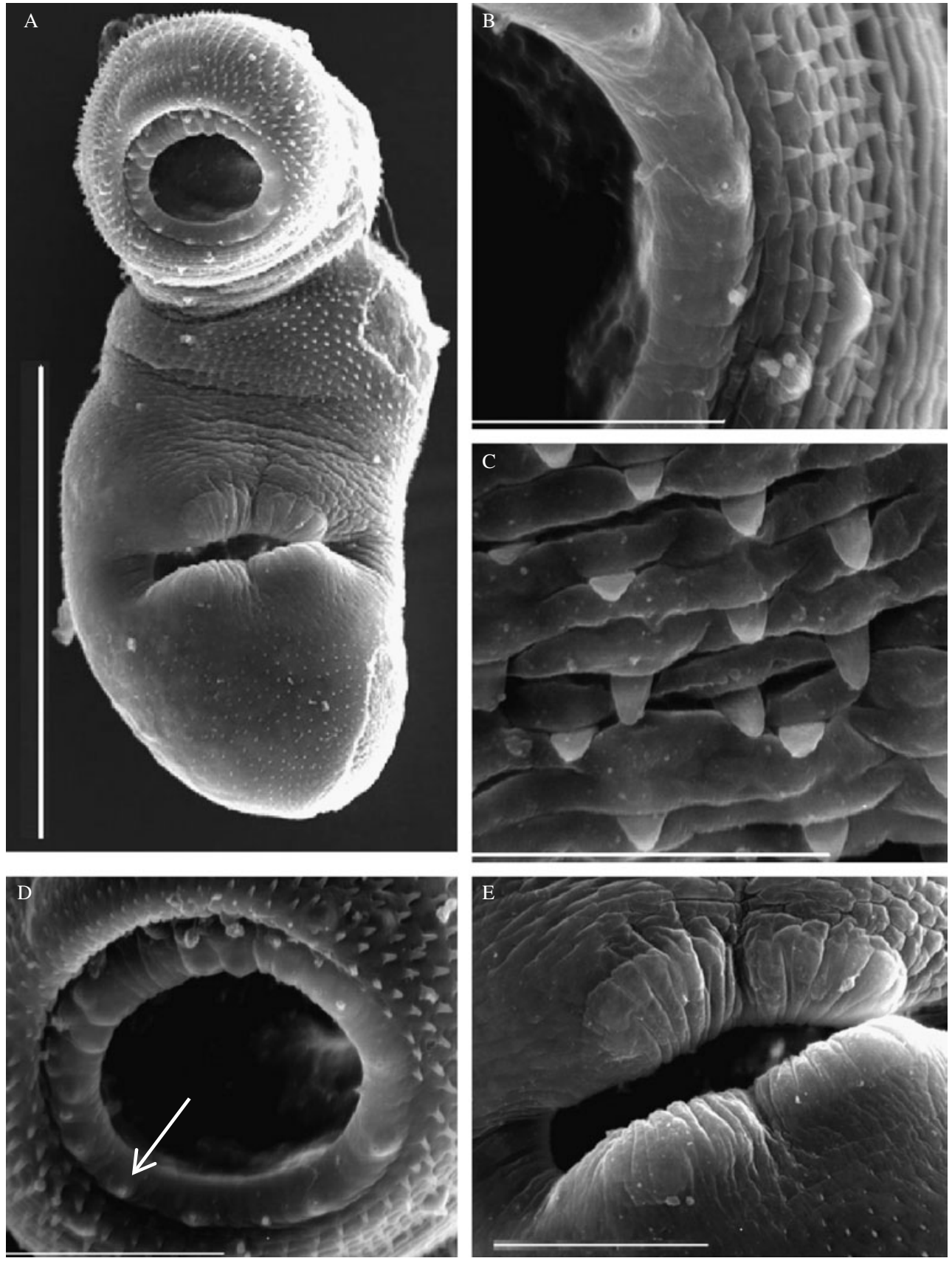

Fig. 3. Metacercariae of Diphtherostomum brusinae: (A) the body surface of a metacercaria, covered with spines; (B) small and pointed spines next to the oral region; $(C)$ strong and triangular spines in the ventral region; (D) papillae (arrow) around the oral sucker; (E) ventral sucker with muscular lips. Scale bars: $100 \mu \mathrm{m}$ (A); $2 \mu \mathrm{m}$ (B); $6 \mu \mathrm{m}(\mathrm{C}) ; 20 \mu \mathrm{m}(\mathrm{D}, \mathrm{E})$.

the oral sucker (fig. 3D). The ventral sucker had a conspicuous lip with four muscular masses (fig. 3E).

\section{Molecular analysis}

The PCR amplification of the $18 \mathrm{~S}$ gene-coding region provided a single fragment with a length of $293 \mathrm{bp}$. Comparative analysis of the sequences from cercariae isolated from $N$. reticulatus, metacercariae from $C$. edule and metacercariae found in M. galloprovincialis confirmed that there was no intraspecific polymorphism, with $100 \%$ homology among all the sequences. All sequences were deposited in GenBank under the accession nos. GQ2443315 (cercariae from $N$. reticulatus), GQ244316 (metacercariae from C. edule), FJ768460, FJ768461 and FJ768462 (metacercariae from M. galloprovincialis for site 


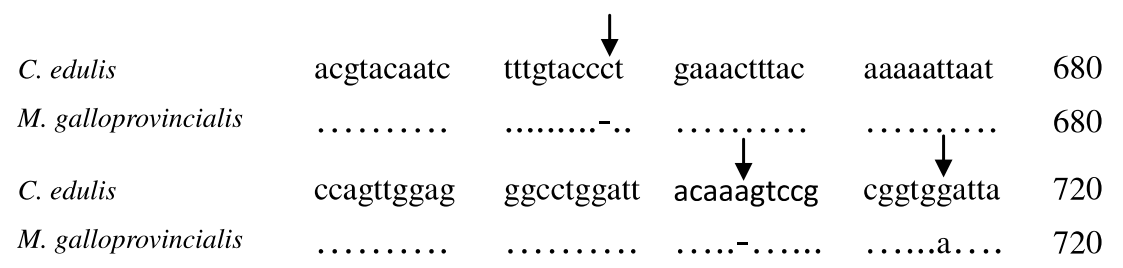

Fig. 4. Fragment of the sequence alignment of the ITS1 region of Diphtherostomum brusinae metacercariae isolated from Cerastoderma edule and from Mytilus galloprovincialis. Arrows, polymorphic sites (two deletions and one substitution).

A, B and C, respectively). The PCR amplification of the ITS1 was performed over two randomly chosen individuals of $D$. brusinae infecting $M$. galloprovincialis and generated a fragment of $1423 \mathrm{bp}$, accession no. GU471863. Direct sequencing of this fragment and alignment (Fig. 4) with the previously available ITS1 sequences from $D$. brusinae infecting $N$. reticulatus and C. edule showed intraspecific polymorphism (there was $99 \%$ homology in the gene portion analysed among all D. brusinae).

\section{Discussion}

This work is the first report of D. brusinae metacercariae infecting the new second intermediate host M. galloprovincialis, with support from morphological and molecular data. Its ecology and infection levels have been reported in a previous paper, where $D$. brusinae was not yet identified to the species level, and therefore is reported as Diphtherostomum sp. (Francisco et al., 2010). In Portugal, D. brusinae was reported for the first time during a study conducted on the larval stages of digenean species that infect the molluscs C. edule and N. reticulatus in the Aveiro estuary (Russell-Pinto et al., 2006). The life cycle of this parasite has previously been described for the Black Sea, with $N$. reticulatus and $C$. donovani as first intermediate hosts and potential second intermediate hosts. Venus gallina, S. subtruncata and C. edule serve only as second intermediate hosts (Dolgikh \& Naidjenovav, 1967; Pina et al., 2009), like M. galloprovincialis in the Aveiro estuary.

In this work, the morphological measurements of the body, oral sucker and ventral sucker were at variance with those presented by Palombi (1930, 1934), Prévot (1966) and Pina et al. (2009). However, this may be due to our having used fresh worms in this study, while the other authors used fixed worms. The D. brusinae observed in the present work had a higher mean body length $(408.5 \mu \mathrm{m})$. The mean dimensions of the oral $(34.5 \mu \mathrm{m})$ and ventral sucker $(54.2 \mu \mathrm{m})$ are also different from those reported by the same authors $(56.0 \mu \mathrm{m}$ and $90.8 \mu \mathrm{m}$, respectively). The metacercarial stage can be found at different levels of development in a host, and thus presents different sizes. Besides that, some morphological variability has also been reported for the adult of D. brusinae when infecting different host species (Bray \& Gibson, 1986; Pina et al., 2009). These authors reported a body length range between 600 and $1228 \mu \mathrm{m}$, oral sucker $60-132 \mu \mathrm{m}$ and ventral sucker $130-251 \mu \mathrm{m}$. Thus, those aspects should be taken into account when comparing different worms.
Using SEM, we observed that the metacercaria body surface was covered with regularly distributed spines, but the morphology and size of the spines changed with the body region. The body of the parasite presented a gradual distribution of sizes of the spines on the surface. Next to the oral region the spines were small and pointed, slightly different from the short and rounded spines described by Pina et al. (2009) for this same region. In the ventral (fig. 3C) and pre-acetabular region, the spines were strong and triangular but not arranged in a rectangular band as noted by Pina et al. (2009). A ring with 16 papillae was observed around the oral sucker (fig. 3D), but none presented a short cilium, as observed by Pina et al. (2009). The ventral sucker has a conspicuous lip with four muscular masses (fig. 3E) and the same was described by Pina et al. (2009). The morphological variations of the spines, when compared to the parasites described by Pina et al. (2009), may be related to the fact that we are dealing with metacercariae in different developmental stages. Successive stages of tegument formation were reported for spiny metacercariae during the development of several microphallidae species (Galaktionov et al., 1996).

For molecular characterization of this parasite, a partial region of the $18 \mathrm{~S}$ rDNA gene was studied from the metacercariae found in M. galloprovincialis and compared with corresponding sequences of cercariae of $D$. brusinae from $N$. reticulatus and metacercariae from $C$. edule. The aligned sequences of $18 \mathrm{~S}$ rDNA gene of all the samples showed $100 \%$ identity. Thus, there is no intraspecific variation among different isolates of the parasites from different hosts. Therefore, we used the highly polymorphic ITS1 region and compared this sequence from randomly chosen $D$. brusinae individuals from M. galloprovincialis with the available sequences from D. brusinae from $N$. reticulatus and C. edule. The ITS1 genomic region analysed presented variation, meaning that there are fixed polymorphisms in this gene that may be correlated with the morphological differences observed among D. brusinae metacercariae from the different hosts. Intraspecific variability of ITS1 has also been found in other Digenea species, such as Schistosoma japonicum (Van Herwerden et al., 1998).

All the morphology and molecular data collected so far lead us to infer that we studied worms belonging to the species D. brusinae, since no robust differences were found in comparison to previous descriptions. In order to clarify this issue, more studies are needed. Moreover, the adult morphology (of worms developed from M. galloprovincialis metacercariae), and genes 
other than ITS1, or different molecular and biochemical techniques, should be explored.

In conclusion, this is the first study using a combination of morphological characteristics and genetic data from $18 \mathrm{~S}$ and ITS1 rDNA to characterize D. brusinae metacercariae from $M$. galloprovincialis, a new second intermediate host. This allowed us to identify both genetic and morphological variability within this species.

\section{Acknowledgements}

The authors wish to thank the National Institute of Health, Department of Infectious Diseases, without which the realization of this work would not have been possible. We are indebted to CAPES (Coordenação de Pessoal de Nivel Superior, Brazil) for the PhD grant no. 37787-053 to C.J.F. S.P.'s work was supported by the grant SFRH/BD/31767/2006 from FCT (Fundação para a Ciência e Tecnologia, Ministério da Ciência e do Ensino Superior, Portugal). We also wish to thank Margarida Aragão Hermida for English revision.

\section{References}

Bray, R.A. (1986) A revision of the family Zoogonidae Odhner, 1902 (Platyhelminthes:Digenea): Introduction and subfamily Zoogoninae. Systematic Parasitology 9, 3-28.

Bray, R.A. (2001) Family Zoogonidae Odhner, 1902. pp. 605-629 in Bray, R., Gibson, D. \& Jones, A. (Eds) Keys to the Trematoda. Vol. 3, Oxfordshire, UK, CABI and Natural History Museum.

Bray, R.A. \& Gibson, D.I. (1986) The Zoogonidae (Digenea) of fishes from the north-east Atlantic. Bulletin of the British Museum (Natural History). Zoology series 51, 127-206.

Dolgikh, A.V. \& Naidjenovav, N.N. (1967) Contribution to the study of helminth parasites of Diplodus annularis. Scientific Reports of the Superior School. Biological Sciences 11, 13-16 (in Russian).
Francisco, C.J., Hermida, M.A. \& Santos, M.J. (2010) Parasites and symbionts from Mytilus galloprovincialis (Lamark, 1819) (Bivalves: Mytilidae) of the Aveiro Estuary Portugal. Journal of Parasitology 96, 200-205.

Galaktionov, K.V., Malkova, I.I., Irwin, S.W.B., Saville, D.H. \& Maguire, J.G. (1996) Developmental changes in the tegument of four microphallid metacercariae in their second (crustacean) intermediate hosts. Journal of Helminthology 70, 201-210.

Hall, A.K., Thomas, H.C. \& Stephen, C.B. (1999) $\mathrm{V} 4$ region of small subunit rDNA indicates polyphyly of the Fellodistomidae (Digenea) which is supported by morphology and life-cycle data. Systematic Parasitology 43, 81-92.

Palombi, A. (1930) Il ciclo biologic di Diphtherostomum brusinae Stossich (Trematode digenetico:fam. Zoogonidadae Odner). Considerazioni sui cicli e volutivi delle specie affini e dei trematodi ni generale. Pubblicazione della Stazione Zoologica di Napoli 10, 111-149.

Palombi, A. (1934) Gli stadi larvali dei Trematode del Golfo di Napoli. $1^{\circ}$ contribuo allo studio della morfologia, biologia e sistemática delle cercarie marine. Pubblicazione della Stazione Zoologica di Napoli 14, 51-94.

Pina, S., Tajdari, J., Russell-Pinto, F. \& Rodrigues, P. (2009) Morphological and molecular studies on life cycle stages of Diphtherostomum brusinae (Digenea: Zoogonidae) from northern Portugal. Journal of Helminthology 83, 321-331.

Prévot, G. (1966) Sur deux Trématodes larvaires d'Antedon mediterrânea Lmk. (Echinoderme). Annales de Parasitologie 41, 233-242.

Russell-Pinto, F., Gonçalves, J.F. \& Bowers, E. (2006) Digenean larvae parasitizing Cerastoderma edule (Bivalvia) and Nassarius reticulatus (Gastropoda) from Ria Aveiro, Portugal. Journal of Parasitology 92, 319-332.

Van Herwerden, L., Blair, D. \& Agatsuma, T. (1998) Intra- and inter-specific variation in nuclear ribosomal internal transcribed spacer 1 of the Schistosoma japonicum species complex. Parasitology 116, 311-317. 